\title{
Efficacy of Probiotics Supplementation on Mineral Digestibility, Haematological Parameters and Carcass Composition of Oreochromis niloticus Fingerlings Fed Canola Meal Based Diets
}

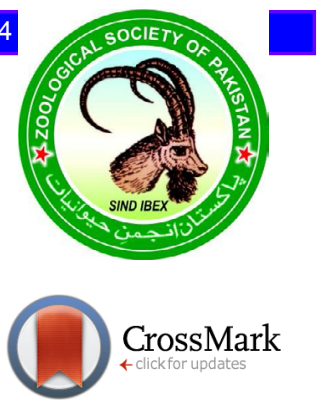

\author{
Syed Makhdoom Hussain ${ }^{1, *}$, Nosheen Aslam², Arshad Javid ${ }^{3}$, Shehzadi Liaquat ${ }^{1}$, \\ Muhammad Mudassar Shahzad ${ }^{1,4}$, Muhammad Zubair-ul-Hassan Arsalan ${ }^{1}$ and \\ Muhammad Adnan Khalid ${ }^{1}$ \\ ${ }^{1}$ Fish Nutrition Lab, Department of Zoology, Government College University, Faisalabad \\ ${ }^{2}$ Department of Biochemistry, Government College University, Faisalabad \\ ${ }^{3}$ Department of Wildlife and Ecology, University of Veterinary and Animal Sciences, \\ Lahore \\ ${ }^{4}$ Department of Zoology, Division of Science and Technology, University of Education \\ Township Campus Lahore
}

\begin{abstract}
A B S T R A C T
Present trial was conducted to evaluate effects of probiotics on mineral absorption, haematology and carcass composition of Oreochromis niloticus fingerlings fed canola meal-based diet. Six test diets were prepared by using graded levels of probiotics (Protexin) such as $0,1,2,3,4$ and $5 \mathrm{gKg}^{-1}$ level in the canola meal based diet. Triplicate tanks were used for each treatment and 15 fingerlings were stocked in each replicate. Fingerlings were fed at the rate of $5 \%$ of live wet weight. Plant meal based diets in the absence of probiotics played negative effect on fish growth performance. Chromic oxide (1\%) was added in the diets as inert marker. It was noted that probiotics supplementation played a significant role in improving absorption of minerals, carcass composition and haematology of fish. Higher mineral digestibility (Ca $76 \%$, Fe $62 \%$, Zn $57 \%$, P $76 \%$ ) and carcass composition (crude protein $17 \%$ and crude fat $10 \%$ ) was found in fish fed on $3 \mathrm{gKg}^{-1}$ level of probiotics supplemented canola meal based diet. Whereas higher $\mathrm{ADC} \%$ of $\mathrm{Na}(75 \%), \mathrm{K}(67 \%)$ and $\mathrm{Mg}(62 \%)$ were recorded by fish fed on $4 \mathrm{gKg}^{-1}$ level of probiotics supplemented canola meal based diet. Similarly maximum improvements in RBCs, WBCs and $\mathrm{Hb}$ as well as higher mineral absorptions were recorded in fish fed on the said test diet. On the basis of these results it was concluded that probiotics supplementation at $3 \mathrm{gKg}^{-1}$ level in canola meal based diet is helpful for maximum performance of Oreochromis niloticus fingerlings.
\end{abstract}

Article Information
Received 11 September 2017
Revised 26 December 2017
Accepted 24 April 2018
Available online 07 August 2018
Authors' Contribution
SMH planned and supervised this
research and provided facilities for
it. NS did biochemical analysis. AJ
interpreted the results statistically.
SL conducted the study, collected
data and prepared manuscript. MMS
helped in compiling the results. MZHA
did feeding trials and collection of
data. AK helped in chemical analysis.
Key words
Canola meal, Probiotics, Oreochromis
niloticus, Mineral digestibility.

\section{INTRODUCTION}

A quaculture is the fastest growing source of animal protein. Aquaculture currently provides about half of all the fish consumed globally (Bostock et al., 2010). Feed primarily accounts for 50 to $60 \%$ of total cost in fish culture (Essa et al., 2010). Fish meal (FM) is a major protein source in aqua feeds for different fish species because it is an excellent source of essential nutrients such as indispensable amino acids, essential fatty acids and a number of attractants (Dawood et al., 2015). The fish meal prices are rising continuously from few decades and are likely to increase more with continued increase in demand (FAO, 2010). Consequently, restricted FM supplies cannot meet longer to the needs of the expanding

\footnotetext{
Corresponding author: drmakhdoom90@gmail.com 0030-9923/2018/0005-1825 \$ 9.00/0

Copyright 2018 Zoological Society of Pakistan
}

fish-feed industry (Bostock et al., 2010). The main objective for most fish farmers is to produce high quality fish feed at low cost. Plant proteins, which are usually considered as low cost as compared to fish meal have been utilized as a substitute in diets for fresh water fishes (Hussain et al., 2015; Wang et al., 2015). Therefore, search for the alternatives of fish meal have an international research priority (Hardy, 2010; Kumar et al., 2010).

Hormones, ionospheres, antibiotics and some salts were utilized as growth promoting feed additives (Klaenhammer and Kullen, 1999). Use of probiotics (live micro-organisms) in fish feed is helpful for higher fish performance by improving nutrient digestibility (LaraFlores et al., 2013). Several studies have demonstrated that the use of probiotics improves health of fish, disease resistance and body composition (El-Haroun et al., 2006; Lara-Flores et al., 2010, 2013). Several reports suggest that probiotics supplementation can reduce the cost of culture by improving the growth and feed utilizing efficiency of 
fish (Watson et al., 2008). When administered in suitable amount, give benefits to the health of the host by improving the balance of the micro-biota in the intestine (Verschuere et al., 2000).

In aquaculture, canola meal is commonly used as alternative source of protein instead of fish meal for important fish species. Actual protein contents in canola seed is 36-39\% (Newkirk, 2009). Canola meal contains similar amino acid profile like herring meal protein whereas superior than soybean meal protein (Shafaeipour et al., 2008). On the other hand, canola meal is also economical as compared to fish meal and soybean meal (Sajjadi and Carter, 2004). Canola meal was successfully used in tilapia fingerling's diet with positive effects on overall fish performance (Higgs et al., 1989).

Tilapias are one of the most important freshwater finfish cultured in the world and they represent more or less $6 \%$ of total farmed fish production (FAO, 2010). After carps and salmons, tilapia has become the third most important fish in aquaculture. It is also famous due to rapid growth, excellent performance in intensive production systems, omnivorous eating habits and easy feed acceptance (Boscolo et al., 2001; Furuya et al., 2008). Less information is available for the formulation of plan meal based diets with probiotics supplementation for commercially important fish species. However, the present study was conducted to discover the optimum level of probiotics supplemented canola meal based diet for improvement in minerals absorption, hematological parameters and carcass composition of $O$. niloticus fingerlings.

\section{MATERIALS AND METHODS}

The research was carried out to observe the effects of probiotics supplementation on minerals absorption, haematology and carcass composition of Nile tilapia fingerlings fed canola meal based diet. The experiment was conducted in the Fish Nutrition Laboratory, Department of Zoology, Government College University, Faisalabad.

\section{Fish and experimental conditions}

$O$. niloticus fingerlings were obtained from Government Fish Seed Hatchery, Faisalabad and kept in $\mathrm{V}$-shaped tanks for two weeks to acclimatize them with experimental conditions. Before the start of feeding trial, fingerlings were treated with $\mathrm{NaCl}\left(5 \mathrm{~g} \mathrm{~L}^{-1}\right)$ to make sure that the fingerlings are free from ecto-parasites and to prevent from further fungal infection (Rowland and Ingram, 1991).

Table I.- Ingredients composition (\%) test diets.

\begin{tabular}{lcccccc}
\hline Ingredients & Test diet-I (Control) & Test diet-II & Test diet-III & Test diet-IV & Test diet-V & Test diet-VI \\
\hline Protexin (probiotics) $\mathrm{gKg}^{-1}$ & 0 & 1 & 2 & 3 & 4 & 5 \\
Canola meal & 50 & 50 & 50 & 50 & 50 & 50 \\
Fish meal & 15 & 15 & 15 & 15 & 15 & 15 \\
Wheat flour* & 11 & 10 & 9 & 8 & 7 & 6 \\
Rice polish & 13 & 13 & 13 & 13 & 13 & 13 \\
Fish oil & 07 & 07 & 07 & 07 & 07 & 07 \\
Vitamin premix** & 01 & 01 & 01 & 01 & 01 & 01 \\
Mineral premix*** & 01 & 01 & 01 & 01 & 01 & 01 \\
Ascorbic acid & 01 & 01 & 01 & 01 & 01 & 01 \\
Chromic oxide & 01 & 01 & 01 & 01 & 01 & 01 \\
\hline
\end{tabular}

*Protexin was added at the cost of wheat flour; ${ }^{* *}$ each 100g of vitamin premix contained: Vitamin A, 2000,000 IU; Vitamin D, 400,000 IU; Vitamin $\mathrm{B}_{1}, 125 \mathrm{mg}$; Vitamin E, $160 \mathrm{IU}$; Vitamin $\mathrm{B}_{2}, 2000 \mathrm{mg}$; Vitamin $\mathrm{K}_{3}, 900 \mathrm{mg}$; Vitamin $\mathrm{B}_{6}, 600 \mathrm{mg}$; Folic acid, 200mg; Vitamin B 12 , 3,000 mcg; Calcium pantothenate, 3,000mg; Vitamin C, 1,000mg; Nicotinic acid, 10,000mg. ***each Kg mineral granules contains: Ca (Calcium), 155gm; Mn (Manganese), 2000mg; P (Phosphorous), 135gm; Cu (Copper), 600mg; Mg (Magnesium), 55gm; Co (Cobalt), 40mg; Fe (Iron), 1000 mg; I (Iodine), 40mg; Zn (Zinc), $3000 \mathrm{mg}$; Se (Selenium), 3mg.

Table II.- Chemical composition (\%) of feed ingredients (dry matter basis).

\begin{tabular}{|c|c|c|c|c|c|c|c|}
\hline Ingredients & $\begin{array}{c}\text { Dry matter } \\
(\%)\end{array}$ & $\begin{array}{c}\text { Crude protein } \\
(\%)\end{array}$ & $\begin{array}{c}\text { Crude fat } \\
(\%)\end{array}$ & $\begin{array}{c}\text { Crude fiber } \\
(\%)\end{array}$ & $\begin{array}{l}\text { Ash } \\
(\%)\end{array}$ & $\begin{array}{c}\text { Carbohydrates } \\
(\%)\end{array}$ & $\begin{array}{c}\text { Gross energy } \\
\left(\mathrm{kcal} \mathrm{g}^{-1}\right)\end{array}$ \\
\hline Canola meal & 93.52 & 33.1 & 2.05 & 6.39 & 6.47 & 49.84 & 2.15 \\
\hline Fish meal & 91.63 & 47.21 & 7.23 & 1.19 & 21.56 & 18.14 & 4.67 \\
\hline Wheat flour & 93.04 & 11.23 & 2.44 & 3.09 & 3.16 & 76.86 & 3.22 \\
\hline Rice polish & 94.86 & 13.48 & 13.17 & 12.70 & 11.09 & 45.97 & 3.59 \\
\hline
\end{tabular}


During this acclimatization period, fingerlings were fed on basal diet once daily to apparent satiation (Allan and Rowland, 1992). Water quality parameters such as temperature, $\mathrm{pH}$ and dissolved oxygen (DO) were monitored on daily basis. Air pump was used to supply air by capillary system through-out the experimental period.

\section{Experimental design}

Canola meal was used as test ingredient to formulate six test diets supplemented with different levels $(0,1,2,3$, 4 and $\left.5 \mathrm{gKg}^{-1}\right)$ of probiotics $\left(1 \mathrm{~g}=2 \times 10^{9} \mathrm{CFU}\right)$. One control diet and five probiotics supplemented canola meal based test diets were fed (for 70-days) to six fish groups stocked in triplicate water tanks having 15 fingerlings in each. Diets supplemented with probiotics were compared with control diet to analyze minerals absorption, haematology and carcass composition by using completely randomized design (CRD).

\section{Formulation of experimental diets and feeding protocol for sample collection}

The experimental feed ingredients were purchased from local market and analyzed for chemical composition following AOAC (1995) prior to formulation of the experimental diet. Chromic oxide (1\%) was added as inert marker. In an electric mixer all ingredients were mixed for 10 minutes and fish oil was gradually added during mixing of diet. During this process $10-15 \%$ water was also added to prepare suitable dough and pellets were formed through pelleting machine (Lovell, 1989). All diets were supplemented with respective probiotics level while control diet was not supplemented. All the prepared diets were dried and stored at $4^{\circ} \mathrm{C}$ until use. The fingerlings of $O$. niloticus were fed at the rate of $5 \%$ of live wet weight on their prescribed diet twice daily (morning 8:00 and afternoon 14:00). After the feeding session of two hours, the uneaten diet was washed from each tank by opening the valves. The tanks were washed completely to remove the particles of diets and refilled with water. Feces were collected from the fecal collection tube of each tank by opening the valves consequently for estimation of minerals absorption. Fecal material of each replicated treatment was dried in oven at $60^{\circ} \mathrm{C}$, grinded and stored for chemical analysis.

\section{Mineral estimation}

Diets and feces samples were digested in boiling nitric acid and perchloric acid mixture $(2: 1)$ by following standard methods (AOAC, 1995). After appropriate dilution, mineral contents such as calcium $(\mathrm{Ca})$, magnesium $(\mathrm{Mg})$, iron $(\mathrm{Fe})$, zinc $(\mathrm{Zn})$ and manganese $(\mathrm{Mn})$ were estimated using Atomic Absorption Spectrophotometer (Hitachi Polarized Atomic Absorption Spectrometer,
Z-8200). Calibrated standards for mineral estimation were prepared from commercially available standards (AppliChem ${ }^{\circledR}$ Gmbh Ottoweg4, DE-64291 Darmstadt, Germany). The estimations of sodium $(\mathrm{Na})$ and potassium (K) were done through flame photometer (Jenway PFP-7, UK). Phosphorus (P) was analyzed calorimetrically (UV/ VIS spectrophotometer) using ammonium molybdate as reagent at $720 \mathrm{~nm}$ absorbance through standard methods (AOAC, 1995). Chromic oxide contents in the diets and feces were estimated after oxidation with molybdate reagent by using a UV-VIS 2001 Spectrophotometer at $370 \mathrm{~nm}$ absorbance (Divakaran et al., 2002). At the end of the experiment minerals absorption was calculated indirectly by using chromic oxide as inert marker. It was calculated by using standard formula (NRC, 1993):

Absorption $(\%)=100-100 \times(\%$ marker in diet $\times \%$ nutrient in feces $/ \%$ marker in feces $\times \%$ nutrient in diet)

\section{Chemical analysis of carcass composition}

Three fish from each replicate were selected and sacrificed for the analysis of carcass composition by standard methods (AOAC, 1995). Gross energy in whole body was determined with the help of oxygen bomb calorimeter (Parr Instrument Co., Moline, USA). Moisture contents were analyzed by using the oven drying at $105^{\circ} \mathrm{C}$ for $12 \mathrm{~h}$ and crude protein $(\mathrm{N} \times 6.25)$ by Micro Kjeldahl apparatus. Crude fat were examined by petroleum ether extraction method through Soxtec HT2 1045 system and crude fiber as loss on ignition of dried lipid-free residues after digestion with $1.25 \% \mathrm{H}_{2} \mathrm{SO}_{4}$ and $1.25 \% \mathrm{NaOH}$. Ash was determined by ignition at $650^{\circ} \mathrm{C}$ for $12 \mathrm{~h}$ in electric furnace to constant heat (Eyela-TMF 3100). Total carbohydrates were calculated by i.e.:

$$
\begin{gathered}
\text { Total carbohydrates }(\%)= \\
100-(\text { protein } \%+\text { fat } \% \text { crude fiber } \%+\text { Ash })
\end{gathered}
$$

\section{Haematology}

After 70 days of the experiment blood samples were collected by selecting three fish from each tank and were anesthetized with $150 \mathrm{mg}^{-1}$ solution of tricane methane sulfonate (Wagner et al., 1997). Blood was taken from caudal vein of anesthetized fish using heparinized syringe and then blood samples were taken to the Molcare Lab, Department of Biochemistry, University of Agriculture, Faisalabad, Pakistan for analysis of hematological indices. Micro-hematocrit technique was used to determine hematocrit by the help of capillary tubes (Brown, 1980). Red blood cells (RBCs) and white blood cells (WBCs) were counted with a haemo-cytometer with approved Neubauer counting chamber (Blaxhall and Daisley, 1973). 


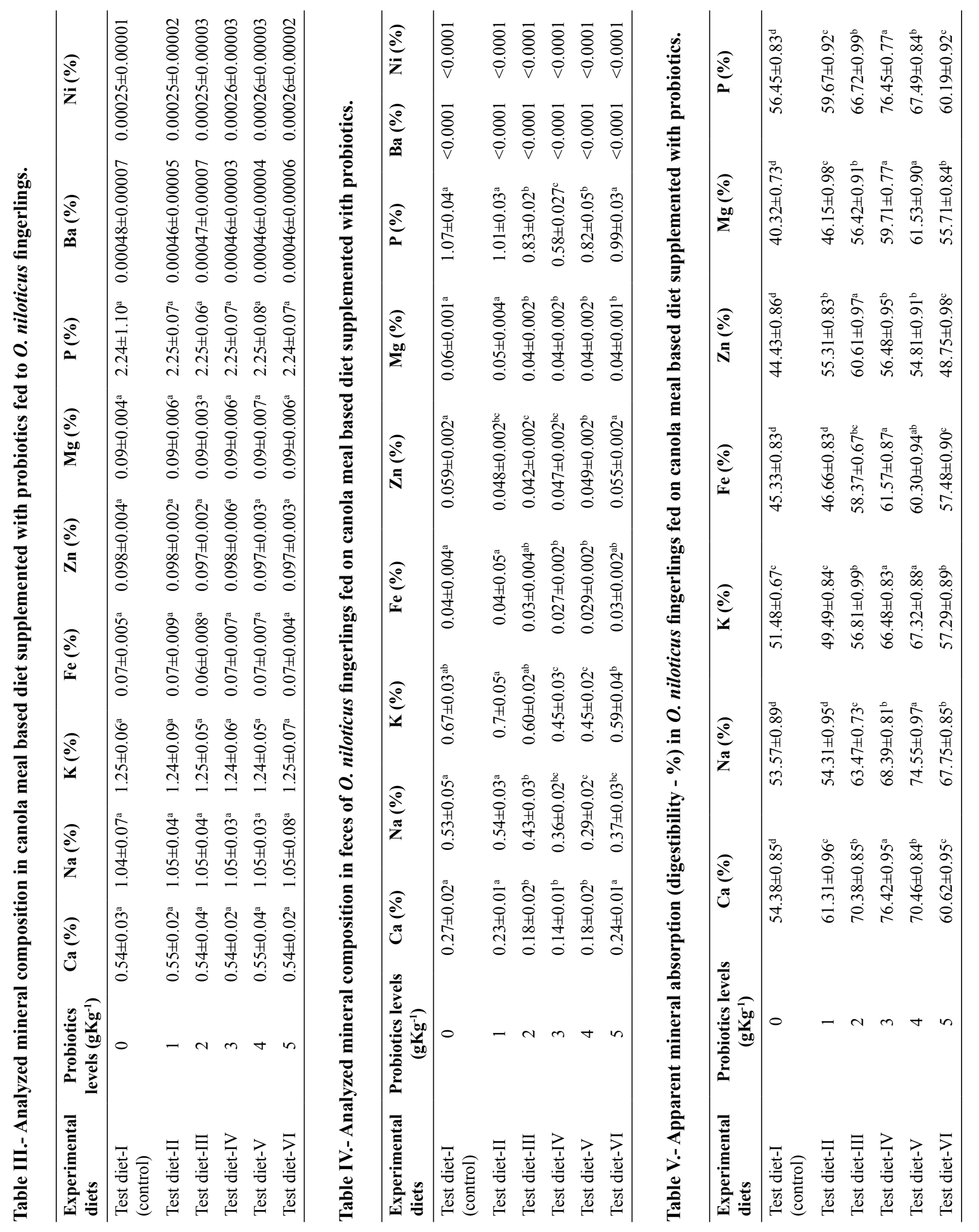


Wedemeyer and Yastuke (1977) method was used to estimate hemoglobin $(\mathrm{Hb})$. Whereas, mean corpuscular hemoglobin concentration (MCHC), mean corpuscular volume (MCV) and mean corpuscular hemoglobin (MCH) were determined by using following formulae:

$$
\begin{gathered}
\mathrm{MCV}=\mathrm{PCV} / \mathrm{RBC} \times 10 \\
\mathrm{MCH}=\mathrm{Hb} / \mathrm{RBC} \times 10 \\
\mathrm{MCHC}=\mathrm{Hb} / \mathrm{PCV} \times 100
\end{gathered}
$$

\section{Statistical analysis}

Data of mineral digestibility, carcass composition and haematology of fish fed with control and test diets were subjected to one-way analysis of variance (Steel et al., 1996). According to Snedecor and Cochran (1991) differences among means were compared by Tukey's Honestly Significant Difference Test and considered significant at $p<0.05$. The CoStat computer software (Version 6.303, PMB 320, Monterey, CA, 93940 USA) was used for statistical analysis.

\section{RESULTS}

Current results showed that amount of minerals in control and test diets was similar with each other, it shows that all diets contain equal amount of minerals (Table III). Whereas, minerals contents in feces of tilapia fed on canola meal based diet supplemented with probiotics were significantly different from each other (Table IV). It was found that minimum amount of minerals such as calcium $(\mathrm{Ca})$, sodium $(\mathrm{Na})$, potassium $(\mathrm{K})$, iron $(\mathrm{Fe})$, zinc $(\mathrm{Zn})$, phosphorous $(\mathrm{P})$ and magnesium $(\mathrm{Mg})$ were discharged through feces at 2, 3 and $4 \mathrm{gKg}^{-1}$ probiotics supplemented canola meal based diet. On the other hand, higher minerals were discharged through feces when fingerlings were fed on control diet.

Results showed that different levels of probiotics in canola meal based diet significantly increased mineral absorption in $O$. niloticus fingerlings as compared to control diet. Maximum mineral absorption values of $\mathrm{Ca}$ $(76 \%), \mathrm{Fe}(62 \%)$ and $\mathrm{P}(76 \%)$ were observed in fish fed on $3 \mathrm{~g} \mathrm{Kg}^{-1}$ level based diet that differed significantly when compared to the fish fed on control and other levels of test diets as shown in Table V. Whereas second higher values (Ca 70\%, Fe 60\% and P 67\%) were found in fish fed at 4 $\mathrm{gKg}^{-1}$ level based diet that were statistically similar (Ca $70 \%$, Fe 58\% and $\mathrm{P} 67 \%$ ) with the values found in fish fed on test diet III $\left(2 \mathrm{gKg}^{-1}\right)$. It was found that highest $\mathrm{Na}(75 \%)$, $\mathrm{Mg}(61 \%)$ and $\mathrm{K}(67 \%)$ were absorbed in fish body when they were fed with $4 \mathrm{gKg}^{-1}$ level based diet as compared to the control and other test diets. In contrary to these, maximum $\mathrm{Zn}(61 \%)$ absorption was found in fingerlings fed on $2 \mathrm{gKg}^{-1}$ level based diet followed (56\%) by fish fed at $3 \mathrm{gKg}^{-1}$ level of probiotics supplemented canola meal based diet. On the other hand lowest mineral absorptions values such as $\mathrm{Ca} 54 \%$, Fe 45\%, P 56\% Na 54\%, Mg 40\% and $\mathrm{Zn} 44 \%$ were observed when fingerlings fed on control diet (without probiotics supplementation). In general, maximum minerals absorption and lowest excretion was found in fish fed $3 \mathrm{gKg}^{-1}$ level based diet that confirms that this level was optimum for the higher mineral absorption and fish performance. On the other hand values of $\mathrm{Ba}$ and $\mathrm{Ni}$ were recorded too much low in diets that they could not be analyzed in feces as well as $\mathrm{ADC} \%$ in $O$. niloticus fingerlings.

Hematological indices of fingerlings fed canola meal based diet supplemented with probiotics shown in Table VI. Results showed that highest values of RBCs $\left(3.17 \times 10^{6}\right.$ $\left.\mathrm{mm}^{-3}\right)$, WBCs $\left(8.18 \times 10^{3} \mathrm{~mm}^{-3}\right)$ and PLT (68.7) were recorded in fish fed with $3 \mathrm{gKg}^{-1}$ level based diet followed by (RBCs $2.99 \times 10^{6} \mathrm{~mm}^{-3}$, WBCs $7.94 \times 10^{3} \mathrm{~mm}^{-3}$ and PLT 66.6) fish fed with $4 \mathrm{gKg}^{-1}$ level of probiotics supplemented canola meal based diet. It was found that these values were significantly different from the values found in fish fed on control diet. On the other hand, lowest RBCs $\left(1.86 \times 10^{6} \mathrm{~mm}^{-}\right.$ $\left.{ }^{3}\right)$ and WBCs $\left(6.92 \times 10^{3} \mathrm{~mm}^{-3}\right)$ were found in fingerlings fed on test diet II $\left(1 \mathrm{gKg}^{-1}\right.$ probiotics level $)$. The lowest PLT value (58.8) was found in fish fed on control diet. It was also found that on higher concentrations of probiotics $\left(5 \mathrm{gKg}^{-1}\right)$ supplementation, the values of WBCs and RBCs could not be improved. Results of hemoglobin $(\mathrm{Hb})$ showed that the fish fed by $3 \mathrm{gKg}^{-1}$ level based diet had highest value $(8.84 \mathrm{~g} / 100 \mathrm{ml})$ as compared to fish fed on control and other test diets. Second higher value $(8.45 \mathrm{~g} / 100 \mathrm{ml})$ was noted when fish fed on $4 \mathrm{gKg}^{-1}$ level based diet and it was statistically similar with the values $(8.35 \mathrm{~g} / 100 \mathrm{ml})$ observed in fish fed on test diet III $\left(2 \mathrm{gKg}^{-1}\right)$. However, lowest $\mathrm{Hb}(6.7 \mathrm{~g} / 100 \mathrm{ml})$ was found in fish fed on control diet. The highest values of PCV (26.5\%), MCHC (34.7\%) and $\mathrm{MCH}(46.2 \mathrm{pg})$ were found in fish fed on $3 \mathrm{gKg}^{-1}$ level based followed by PCV $25.5 \%$, MCHC $34 \%$ and $\mathrm{MCH}$ $45 \mathrm{pg}$ from fish fed on $4 \mathrm{gKg}^{-1}$ level based diet. These values were significantly different from fish fed on other diets i-e control, 1, 2 and $5 \mathrm{gKg}^{-1}$ levels probiotics based diets. Whereas lowest PCV (20.1\%), MCHC (26.6\%) and $\mathrm{MCH}(31.6 \mathrm{pg}$ ) values were observed in fish fed on control diet (without probiotics supplementation). Results showed that fish fed test diet III showed the highest value (194.4 fl) of MCV followed (180.5 fl) by fish fed on test diet IV. This value was significantly different from other levels. Lowest MCV value (99.5 fl) was found in fingerlings fed on control diet. 
Table VI.- Analysis of haematological parameters of $O$. niloticus fingerlings fed on canola meal based diets supplemented with probiotics (protexin).

\begin{tabular}{|c|c|c|c|c|c|c|c|c|c|}
\hline $\begin{array}{l}\text { Experimental } \\
\text { diets }\end{array}$ & $\begin{array}{c}\text { Probiotics } \\
\text { levels }\left(\mathrm{gKg}^{-1}\right)\end{array}$ & $\begin{array}{c}\text { WBCs } \\
10^{3} \mathrm{~mm}^{-3}\end{array}$ & $\begin{array}{c}\text { RBCs } \\
10^{6} \mathrm{~mm}^{-3}\end{array}$ & PLT & $\begin{array}{c}\text { Hb } \\
(\mathrm{g} / 100 \mathrm{ml})\end{array}$ & $\begin{array}{l}\text { PCV } \\
(\%)\end{array}$ & $\begin{array}{c}\text { MCHC } \\
(\%)\end{array}$ & $\begin{array}{c}\mathrm{MCH} \\
\text { (pg) }\end{array}$ & $\begin{array}{l}\text { MCV } \\
\text { (fl) }\end{array}$ \\
\hline $\begin{array}{l}\text { Test diet-I } \\
\text { (control) }\end{array}$ & 0 & $7.00 \pm 0.13^{\mathrm{cd}}$ & $1.74 \pm 0.07^{\mathrm{c}}$ & $58.8 \pm 0.29^{f}$ & $6.7 \pm 0.16^{\mathrm{c}}$ & $20.1 \pm 0.22^{\mathrm{e}}$ & $26.6 \pm 0.29^{d}$ & $31.6 \pm 0.35^{\mathrm{d}}$ & $99.5 \pm 0.36^{f}$ \\
\hline Test diet-II & 1 & $6.92 \pm 0.06^{\mathrm{d}}$ & $1.86 \pm 0.08^{\mathrm{c}}$ & $61.7 \pm 0.24^{\mathrm{e}}$ & $7.15 \pm 0.22^{\mathrm{c}}$ & $21.5 \pm 0.32^{\mathrm{d}}$ & $27.5 \pm 0.27^{\mathrm{c}}$ & $32.4 \pm 0.28^{\mathrm{d}}$ & $107.6 \pm 0.33^{\mathrm{e}}$ \\
\hline Test diet-III & 2 & $7.77 \pm 0.16^{\mathrm{b}}$ & $2.55 \pm 0.09^{b}$ & $64.6 \pm 0.19^{c}$ & $8.35 \pm 0.19^{\mathrm{ab}}$ & $23.6 \pm 0.24^{c}$ & $32.5 \pm 0.42^{b}$ & $36.3 \pm 0.25^{\mathrm{c}}$ & $194.4 \pm 0.41^{\mathrm{a}}$ \\
\hline Test diet-IV & 3 & $8.18 \pm 0.13^{\mathrm{a}}$ & $3.17 \pm 0.12^{\mathrm{a}}$ & $68.7 \pm 0.32^{\mathrm{a}}$ & $8.84 \pm 0.27^{\mathrm{a}}$ & $26.5 \pm 0.36^{\mathrm{a}}$ & $34.7 \pm 0.37^{\mathrm{a}}$ & $46.2 \pm 0.25^{\mathrm{a}}$ & $180.5 \pm 0.26^{b}$ \\
\hline Test diet-V & 4 & $7.94 \pm 0.10^{\mathrm{ab}}$ & $2.99 \pm 0.14^{\mathrm{a}}$ & $66.6 \pm 0.30^{\mathrm{b}}$ & $8.45 \pm 0.29^{\mathrm{ab}}$ & $25.5 \pm 0.37^{b}$ & $34.0 \pm 0.33^{\mathrm{a}}$ & $45.0 \pm 0.59^{b}$ & $168.6 \pm 0.34^{\circ}$ \\
\hline Test diet-VI & 5 & $7.30 \pm 0.13^{\mathrm{c}}$ & $2.37 \pm 0.14^{\mathrm{b}}$ & $63.6 \pm 0.19^{d}$ & $7.96 \pm 0.13^{b}$ & $23.3 \pm 0.27^{\mathrm{c}}$ & $32.3 \pm 0.25^{b}$ & $37.2 \pm 0.56^{c}$ & $112.3 \pm 0.44$ \\
\hline
\end{tabular}

RBC, red blood cell; WBC, white blood cell; PLT, platelet; Hb, hemoglobin; PCV, packed cell volume; MCHC, mean corpuscular hemoglobin concentration; $\mathrm{MCH}$, mean corpuscular hemoglobin; MCV, mean corpuscular volume. Means within columns having different superscripts are significantly different at $p<0.0$. Data are means of three replicates.

Table VII.- Carcass composition of $\boldsymbol{O}$. niloticus fingerlings fed on canola meal based diet supplemented with varying levels of probiotics (protexin).

\begin{tabular}{lccccccc}
\hline $\begin{array}{l}\text { Experimental } \\
\text { diets }\end{array}$ & $\begin{array}{c}\text { Probiotics levels } \\
\left(\mathbf{g K g}^{-1}\right)\end{array}$ & Crude protein & Crude fat & Ash & Gross energy & Crude fiber & Moisture \\
\hline $\begin{array}{l}\text { Test diet-I } \\
\text { (control) }\end{array}$ & 0 & $13.67 \pm 0.22^{\mathrm{d}}$ & $6.43 \pm 0.13^{\mathrm{c}}$ & $5.61 \pm 0.19^{\mathrm{ab}}$ & $1.16 \pm 0.14^{\mathrm{b}}$ & $1.02 \pm 0.07^{\mathrm{ab}}$ & $72.11 \pm 0.59^{\mathrm{a}}$ \\
Test diet-II & 1 & $14.84 \pm 0.44^{\mathrm{c}}$ & $8.02 \pm 0.18^{\mathrm{b}}$ & $5.40 \pm 0.11^{\mathrm{b}}$ & $1.34 \pm 0.08^{\mathrm{b}}$ & $0.93 \pm 0.04^{\mathrm{b}}$ & $69.47 \pm 0.43^{\mathrm{b}}$ \\
Test diet-III & 2 & $15.71 \pm 0.28^{\mathrm{b}}$ & $8.45 \pm 0.23^{\mathrm{b}}$ & $5.20 \pm 0.14^{\mathrm{bc}}$ & $1.94 \pm 0.15^{\mathrm{a}}$ & $1.11 \pm 0.09^{\mathrm{ab}}$ & $67.59 \pm 0.47^{\mathrm{c}}$ \\
Test diet-IV & 3 & $17.09 \pm 0.32^{\mathrm{a}}$ & $9.48 \pm 0.30^{\mathrm{a}}$ & $4.93 \pm 0.08^{\mathrm{c}}$ & $1.79 \pm 0.23^{\mathrm{a}}$ & $1.06 \pm 0.07^{\mathrm{ab}}$ & $65.65 \pm 0.05^{\mathrm{d}}$ \\
Test diet-V & 4 & $14.66 \pm 0.12^{\mathrm{c}}$ & $7.92 \pm 0.61^{\mathrm{b}}$ & $5.35 \pm 0.22^{\mathrm{b}}$ & $1.30 \pm 0.07^{\mathrm{b}}$ & $0.96 \pm 0.09^{\mathrm{b}}$ & $69.80 \pm 0.77^{\mathrm{b}}$ \\
Test diet-VI & 5 & $13.31 \pm 0.18^{\mathrm{d}}$ & $6.33 \pm 0.23^{\mathrm{c}}$ & $5.84 \pm 0.11^{\mathrm{a}}$ & $1.08 \pm 0.09^{\mathrm{b}}$ & $1.16 \pm 0.05^{\mathrm{a}}$ & $72.29 \pm 0.22^{\mathrm{a}}$ \\
\hline
\end{tabular}

All values of means within columns are different significantly $p<0.05$. Data values are mean \pm standard deviation of three replicates.

The proximate composition (on wet basis) of $O$. niloticus fingerlings fed on canola meal based diet supplemented with varying levels of probiotics (protexin) is shown in Table VII. Results showed that the fish fed by 3 $\mathrm{gKg}^{-1}$ level based diet have highest contents of crude protein (17\%) and crude fat $(9.48 \%)$ as compared to fish fed on control diet (protein $13.67 \%$ and fat 6.43 ). Second higher level of crude protein $(15.71 \%)$ and fat $(8.45 \%)$ contents in fish carcass were observed in fish fed on test diet III. Maximum gross energy $\left(1.94 \mathrm{Kcal} \mathrm{g}^{-1}\right)$ was recorded in fish carcass that fed on test diet III followed $\left(1.79 \mathrm{Kcal} \mathrm{g}^{-1}\right)$ by fish fed on test diet IV $\left(3 \mathrm{gKg}^{-1}\right)$ as compared to fingerlings $\left(1.16 \mathrm{Kcal} \mathrm{g}^{-1}\right)$ fed on test diet I (control diet). On the other hand the lowest values (protein $13.31 \%$, fat $6.33 \%$ and gross energy $1.08 \mathrm{Kcal} \mathrm{g}^{-1}$ ) were recorded in fish fed at 5 $\mathrm{gKg}^{-1}$ probiotics supplemented canola meal based diet. It was noted that $3 \mathrm{gKg}^{-1}$ level based diet is able to improve the protein, fat and gross energy contents in fingerlings as compared to control and other probiotics levels based diet. Highest amount of crude ash (5.84\%), crude fiber $(1.16 \%)$ and moisture $(72.29 \%)$ was found in carcass of fish that fed on canola meal based diet supplemented with probiotics at $5 \mathrm{gKg}^{-1}$ followed (crude ash 5.61\%, crude fiber $1.02 \%$ and moisture $72.11 \%$ ) by fish fed on control diet. It was also found that these values (crude ash 5.35\%, crude fiber $0.96 \%$ and moisture $79.80 \%$ ) were statistically at par with the values found in carcass of fish fed at $4 \mathrm{gKg}^{-1}$ level based diet. On the other hand lowest amount of crude ash $(4.93 \%)$ and moisture $(65.65 \%)$ was observed in fish fed on test diet IV, whereas lowest crude fiber $(0.93 \%)$ contents were observed in fish fed on test diet II.

\section{DISCUSSION}

According to results fish fed at $3 \mathrm{gKg}^{-1}$ level based diet showed lowest discharge of minerals as compared to fish fed control and other test diets whereas the highest discharge was recorded when fish fed with $1 \mathrm{gKg}^{-1}$ level based diet. Maximum mineral digestibility was observed in fish fed at $3 \mathrm{gKg}^{-1}$ level based diet as compared to fish fed control and other test diets. Mostly published research on the use of plant protein as a substitute of fish meal in fish feeds has inattentive the inclusion of various unconventional feeds stuff such as Palm kernel meal 
(Chen and Davis, 2002), cotton seed meal (Yue and Zhou, 2008), Faba beans (Azaza et al., 2009). However varied result has been reported with different alternative plant protein sources. Digestibility data of minerals such as $\mathrm{Ca}, \mathrm{Na}, \mathrm{K}, \mathrm{Fe}, \mathrm{Zn}, \mathrm{P}, \mathrm{Mg}, \mathrm{Ba}$ and $\mathrm{Ni}$ showed significant difference when $O$. niloticus fingerlings fed varying levels of probiotics supplemented canola meal based diet. Similarly, Rodrigues et al. (2012) showed that mineral contents such as $\mathrm{Ca}, \mathrm{P}$ and $\mathrm{Mg}$ were absorbed maximum in animals when fed with probiotics (Bifidobacterium longum and Bifidobacterium longum) supplemented yacon flour. Probiotics are live microorganisms, which have beneficial effects on the host by modifying the host-associated or ambient microbial community of the gastrointestinal tract thus promoting better feed utilization and improving the quality of its ambient environment (Verschuere et al, 2000). Although, the importance of probiotics in human and animal nutrition is widely recognized, in recent years, the role of probiotics in nutrition and health of certain aquaculture species have also been investigated and subject of reviews (Merrifield et al., 2010). It appears that probiotics provide benefits by establishing favorable microbial communities such as lactic acid bacteria and Bacillus sp. in the gastrointestinal track which may alter gut morphology and produce certain enzymes and inhibitory compounds causing improved digestion and absorption of minerals and nutrients (Verschuere et al., 2000). Several studies have demonstrated that the use of probiotics improves health of larval and juvenile fish, disease resistance, growth performance and body composition, however, the mode of action in fish species may vary between farmed fish species cultured in freshwater and marine environments. The effects of probiotics have been linked to modulation of gut microbiota and establishment of the beneficial microorganisms, higher specific and total digestive enzyme activities in the brush-border membrane which increases the nutrient digestibility and feed utilization (Watson et al., 2008). Bongers and Heuvel (2003) observed the effects of prebiotics on absorption of minerals fed with probiotics supplemented plant meal based diet. These variations in levels of probiotics used for higher fish performance may be due to variant fish species, diet composition, species of probiotics used in feed and experimental conditions.

In aquaculture, fish hematology is gaining importance due to its consequences in monitoring the fish health (Hrubec et al., 2000). Douglass and Janes (2010) said that WBC plays an important role in immune responses and increases the ability of the animal to fight against infection. RBCs count greater than $1.00 \times 10^{6} \mathrm{~mm}^{-3}$ is considered optimum and show high oxygen carrying capacity of the blood which is characteristic of fishes capable of aerial respiration and with high metabolic activity (Lenfant and Johansen, 1972). The O. niloticus fingerlings showed the highest number of RBCs $\left(3.17 \times 10^{6} \mathrm{~mm}^{-3}\right)$ and WBCs $\left(8.18 \times 10^{3} \mathrm{~mm}^{-3}\right)$ when they fed with $3 \mathrm{gKg}^{-1}$ level based diet whereas the minimum values $\left(1.86 \times 10^{6} \mathrm{~mm}^{-3}\right.$ and $8.18 \times 10^{3} \mathrm{~mm}^{-3}$ ) were observed in fish fed on $1 \mathrm{gKg}$ 1 level based diet. Haematological parameters can be used as an effective index to observe the physiological and pathological changes in fish to detect the fish health (Robertson et al., 2000). Similarly, Krishnaveni et al. (2013) found higher RBCs in C. catla when fingerlings fed on soybean meal based diet supplemented with probiotics at the level of $3 \%$. Similar to present results, platelets count was increased with increasing level of probiotics and resulted in an increase in the number of thrombocyte, lymphocyte and hematocrit percentage in tilapia after supplementation of probiotics (Martins et al., 2008). in another study, similarly to present study WBCs showed increasing trend from 1 to $3 \mathrm{gKg}^{-1}$ level based diet (Krishnaveni et al., 2013). Olalusi et al. (2014) found that WBCs increases with increasing level of probiotics while Salinas et al. (2008) reported the use of two different bacterial strains such as $L$. delbrueckii lactis and B. subtilis could be more effective for higher number of blood cells than a mono-strain probiotic. According to present results platelets count (68.7) was also higher with increasing level of probiotics (up-to 3\%) as reported by Krishnaveni et al. (2013). They also found maximum PLT when $C$. catla fingerlings fed with $3 \%$ probiotics supplemented soybean meal based diet. Similarly, increase in the number of thrombocyte, lymphocyte and hematocrit percentage was also found in tilapia after supplementation of Enterococcus sp. (Martins et al., 2008). In present study haemoglobin (Hb), corpuscular haemoglobin concentration (MCHC) and mean corpuscular haemoglobin $(\mathrm{MCH})$ analysis showed that the fish fed with 2,3 , and $4 \mathrm{gKg}^{-1}$ level of probiotics supplementation in canola meal based diet had significantly highest values as compared to fish fed on control and other test diets. Krishnaveni et al. (2013) found higher $\mathrm{Hb}$ in $\mathrm{C}$. catla fingerlings fed with $3 \%$ probiotics supplemented soybean meal based diet. Similar to current study, highest value $(26.5 \%)$ of packed cell volume (PCV) was noted in fish fed at $3 \mathrm{gKg}^{-1}$ level based diet (Olalusi et al., 2014). Krishnaveni et al. (2013) observed highest $\mathrm{MCV}$ in fish fed at 3\% level based diet.

The amino acid profile of canola meal is superior to soybean meal protein (Thiessen et al., 2004). As the principal and most expensive component in tilapia diets, protein has received the most attention in nutritional requirement studies. Tilapia needs continuous supply of protein which is necessary for maintenance, growth and reproduction (NRC, 1993). In the present study it was 
observed that the highest carcass values such as crude protein $(17 \%)$ and crude fat $(10 \%)$ were found in fish fed with $3 \mathrm{gKg}^{-1}$ level of probiotics supplemented diet but gross energy was found highest (1.94) in fish fed with test diet supplemented with $2 \mathrm{gKg}^{-1}$ level of probiotics. But at higher levels of probiotics in canola meal based diets showed decreased nutrient utilization in fish body. However, Dhanaraj et al. (2010) observed improved carcass composition (48\% protein, $18 \%$ lipid and $23 \%$ carbohydrate) of koi Carp (C. carpio) fingerlings fed at $0.5 \%$ of probiotics supplemented soybean meal based diet. Whereas, Mazurkiewicz et al. (2005) found higher protein $(15 \%)$ and fat contents $(3 \%)$ in C. carpio fingerlings when they were fed on $1 \mathrm{gKg}^{-1}$ probiotics supplemented soybean meal based diet. Bagheri et al. (2008) found the maximum protein values of carcass in $O$. mykiss fed at $3.8 \times 10^{9} \mathrm{CFU}$ $\mathrm{g}^{-1}$ level in plant meal based diet as compared to fish fed on control and other test diets. El-Komy et al. (2014) found highest crude protein in Nile tilapia fed $1 \mathrm{gKg}^{-1}$ level of probiotics supplemented soybean meal based diet. Present results were almost similar to Essa et al. (2010). They found higher protein contents in fish fingerlings fed at $10^{7} \mathrm{CFU} \mathrm{g^{-1 }}$ supplemented soybean meal based diet. In contrary to these results higher fat contents were found in fish fed with control diet as compared to fish fed on test diets (Bagheri et al., 2008). Essa et al. (2010) also observed highest lipid contents when Nile tilapia fed at $10^{7} \mathrm{CFU}$ $\mathrm{g}^{-1}$ level of probiotics soybean meal based diet. Similar with the present results it was observed that minimum moisture contents were found in fish fed on $3.8 \times 10^{9} \mathrm{CFU}$ $\mathrm{g}^{-1}$ probiotics level based diet (Bagheri et al., 2008). Essa et al. (2010) also found lowest moisture contents when tilapia fed at $10^{7} \mathrm{CFU} \mathrm{^{-1 }}$ probiotics supplemented soybean based diet.

\section{CONCLUSION}

It was concluded that $3 \mathrm{gKg}^{-1}$ level based diet is the optimum level that has a significant role in improving mineral absorption, hematology and carcass composition of $O$. niloticus fingerlings.

Statement of conflict of interest

Authors have declared no conflict of interest.

\section{REFERENCES}

Allan, G.L. and Rowland, S.J., 1992. Development of an experimental diet for silver perch (Bidynus bidyanus). Austasia Aquacul., 6: 39-40.

AOAC, 1995. Official methods of analysis, $15^{\text {th }} \mathrm{Ed}$. Association of Official Analytical Chemists, Washington D.C., USA., pp. 1094.
Azaza, M.S., Wassim, K., Mensi, F., Abdelmouleh, A., Brini, B. and Kraiem, M.M., 2009. Evaluation of faba beans (Vicia faba L. var. minuta) as a replacement for soybean meal in practical diets of juvenile Nile tilapia, Oreochromis niloticus. Aquaculture, 287: 174-179. https://doi. org/10.1016/j.aquaculture.2008.10.007

Bagheri, T., Hedayati, S.A., Yavari, V., Alizade, M. and Farzanfar, A., 2008. Growth, survival and gut microbial load of rainbow trout (Onchorhynchus mykiss) fry given diet supplemented with probiotic during the two months of first feeding. Turkish $J$. Fish. aquat. Sci., 8: 43-48.

Blaxhall, P.C. and Daisley, K.W., 1973. Routine haematological methods for use with fish blood. J. Fish Biol., 6: 771-781. https://doi. org/10.1111/j.1095-8649.1973.tb04510.x

Bongers, A. and Heuvel, V.D., 2003. Prebiotics and the bioavailability of minerals and trace elements. $F d$. Rev. Int., 19: 397-422. https://doi.org/10.1081/FRI120025482

Boscolo, W.R., Hayashi, C., Meurer, F. and Soares, C.M., 2001. Farinhas de peixe, carne e ossos, vísceras e crisálida como atractantes em dietas para alevinos de tilápia do Nilo (Oreochromis niloticus). Rev. Bras. Zootec., 30: 1397-1402. https://doi. org/10.1590/S1516-35982001000600002

Bostock, J., McAndrew, B., Richards, R., Jauncey, K., Telfer, T., Lorenzen, K., Little, D., Ross, L., Handisyde, N., Gatward, I. and Corner, R., 2010. Aquaculture: global status and trends. Phil. Trans. R. Soc. B, 365: 2897-2912. https://doi.org/10.1098/ rstb. 2010.0170

Brown, B.A., 1980. Hematology: Principles and procedures. Lippincott Williams and Wilkins publishers. pp. 71-112.

Chen, L. and Davis, N.G., 2002. Ubiquitin-independent entry into the yeast recycling pathway. Traffic, 3: $110-123$. https://doi.org/10.1034/j.16000854.2002.030204.x

Dawood, M.A.O., Koshio, S., Ishikawa, M. and Yokoyama, S., 2015. Effects of partial substitution of fish meal by soybean meal with or without heatkilled Lactobacillus plantarum (LP20) on growth performance, digestibility, and immune response of Amberjack, Seriola dumerili Juveniles. BioMed Res. Int., 2015: Article ID 514196. https://doi. org/10.1155/2015/514196

Dhanaraj, M., Haniffa, M.A., Singh, S.V.A., Arockiaraj, A.J. and Ramakrishanan, C.M., 2010. Effect of probiotics on growth performance of Koi carp (Cyprinus carpio). J. appl. Aquacul., 22: 202-209. 
Divakaran, S., Leonard, G.O. and Ian, P.F., 2002. Note on the methods for determination of chromic oxide in shrimp feeds. J. Agric. Fd. Chem., 50: 464-567. https://doi.org/10.1021/jf011112s

Douglass, J.W. and Janes, K.W., 2010. Schalm's veterinary haematology. John Wiley and Sons. Blackwell Publishing Limited, pp. 1232.

El-Haroun, E.R., Goda, A. and Kabir, M., 2006. Effect of dietary probiotic Biogen supplementation as a growth promoter on growth performance and feed utilization of Nile tilapia (Oreochromis niloticus (L.)). Aquacul. Res., 37: 1473-1480. https://doi. org/10.1111/j.1365-2109.2006.01584.x

El-Komy, H.M.A. and Shehab El-Din, M., 2014. The effect of different commercial probiotics on growth performance, chemical composition and health status of Nile tilapia (Oreochromis niloticus). $4^{\text {th }}$ Conference of Central Laboratory for Aquaculture Research, pp. 115-131.

Essa, M.A., EL-Serafy, S.S., El-Ezabi, M.M., Daboor, S.M., Esmael, N.A. and Lall, S.P., 2010. Effect of different dietary probiotics on growth, feed utilization and digestive enzymes activities of Nile tilapia (O. niloticus). J. Arabian aquat. Soc., 2: 143-162.

FAO, 2010. The State of World Fisheries and Aquaculture (SOFIA). FAO Fisheries and Aquaculture Department, Food and Agriculture Organization of the United Nations Rome, Italy.

Furuya, M., Ishida, J., Aoki, I. and Fukamizu, A., 2008. Pathophysiology of placentation abnormalities in pregnancy-induced hypertension. Vasc. Hlth. Risk Manage., 4: 1301-1313. https://doi.org/10.2147/ VHRM.S4009

Hardy, R.W., 2010. Utilization of plant proteins in fish diets: Effects of global demand and supplies of fishmeal. Aquacul. Res., 41: 770-776. https://doi. org/10.1111/j.1365-2109.2009.02349.x

Higgs, D.A., Dosanjh, B.S., Little, M., Roy, R.J.J. and McBride, J.R., 1989. Potential for including canola products (meal and oil) in diets for Oreochromis mossambicus $x \mathrm{O}$. aureus hybrids. Proceeding Third International Symposium on Feeding and Nutrition in Fisheries, Toba, Japan, pp. 301-314.

Hrubec, T.C., Cardinale, J.L. and Smith, S.A., 2000. Haematology and plasma chemistry reference intervals for cultured tilapia (Oreochromis hybrid). Vet. clin. Pathol., 29: 7-12. https://doi.org/10.1111/ j.1939-165X.2000.tb00389.X

Hussain, B., Dawar, K. and Abbas, A., 2015. Growth and yield response of maize to nitrogen and phosphorus rates with varying irrigation timings. Environ. $\mathrm{Pl}$.
Syst., 1: 16-21.

Klaenhammer, T.D. and Kullen, M.J., 1999. Selection and design of probiotics. Int. J. Fd. Microbiol., 50: 45-57. https://doi.org/10.1016/S01681605(99)00076-8

Krishnaveni, R., Palanivelu, K. and Velavan, S., 2013. Effects of probiotics and spirulina supplementation on haemato-immunological function of Catla catla. Int. J. Res. Fish. Aquacul., 3: 176-181.

Kumar, V., Makkar, H.P.S. and Becker, K., 2010. Dietary inclusion of detoxified Jatropha curcas kernel meal: Effects on growth performance and metabolic efficiency in common carp, Cyprinus carpio (Linnaeus). Fish Physiol. Biochem., 36: 1159-1170. https://doi.org/10.1007/s10695-0109394-7

Lara-Flores, M., Olivera-Castillo, L. and Olvera-Novoa, M.A., 2010. Effect of the inclusion of a bacterial mix (Streptococcus faecium and Lactobacillus acidophilus), and the yeast (Saccharomyces cerevisiae) on growth, feed utilization and intestinal enzymatic activity of Nile tilapia (Oreochromis niloticus). Int. J. Fish Aquacul., 2: 93-101. https:// doi.org/10.1016/S0044-8486(02)00277-6

Lara-Flores, M., Olvera-Novoa, M.A., GuzmanMendez, B.E. and Lopez-Madrid, W., 2013. Use of the bacteria Streptococcus facium and Lactobacillus acidophilus, and the yeast Saccharomyces cerevisiae as growth promoters in Nile tilapia (Oreochromis niloticus). Aquaculture, 216: 193201.

Lenfant, C. and Johansen, K., 1972. Gas exchange in gill, skin and lung breathing. Resp. Physiol., 14: 211218. https://doi.org/10.1016/0034-5687(72)900291

Lovell, R.T., 1989. Fish nutrition and feeding. Van Nostrand Reinhold Co., New York. https://doi. org/10.1007/978-1-4757-1174-5

Martins, M.L., Mourino, J.L.P., Amaral, G.V., Vieira, F.N., Dotta, G., Bezerra, A.J.M., Pedrotti, F.S., Jeronimo, G.T., Buglione-Neto, C.C. and Pereira Jr, G., 2008. Haematological changes in Nile tilapia experimentally infected with Enterococcus sp. Braz. J. Biol., 68: 631-637. https://doi.org/10.1590/ S1519-69842008000300025

Mazurkiewicz, J., Przybyl, A. and Mroczyk, W., 2005. Supplemementing the feed of common carp juveniles with the biosaf probiotics. Arch. Polish Fish., 13: 171-180.

Merrifield, D.L., Dimitroglou, A., Foey, A., Davies, S.J., Baker, R.T.M., Bøgwald, J., Castex, M. and Ringø, E., 2010. The current status and future focus of 
probiotic and probiotic applications for salmonids. Aquaculture, 302: 1-18. https://doi.org/10.1016/j. aquaculture.2010.02.007

Namam, V.R. and Sreeramulu, K., 2017. Biochemical composition in the muscle tissue of Tilapia mossambica infected with metazoan parasites in culture ponds of Andhra Pradesh. Global J. Res. Analy., 9: 162-164.

NRC, 1993. Nutrient requirements of fish. Committee on Animal Nutrition, Board on Agriculture, National Research Council, National Academy Press, Washington DC, USA.

Newkirk, R., 2009. Canola meal: Feed industry guide. Canadian Int. Grains Inst., Canola Council, Winnipeg, Mannitoba, Canada.

Olalusi, A.C.I., Mojekwu, T., Adeleke, T.A., Edah, B., Adejonwo, M.O. and Adeyemi, Y.B., 2014. Digestive enzymes assay and haematological profile of Clarias gariepinus juveniles fed with probiotics supplemented diets. Adv. Pl. Agric. Res., 1: 00025. https://doi.org/10.15406/apar.2014.01.00025

Robertson, P.A.W., O’Dowd, C., Burrells, C., Williams, P. and Austin, B., 2000. Use Carnobacterium sp. as probiotic for Atlantic salmon (Salmo salar L.) and rainbow trout (Oncorhynchus mykiss, Walbaum). Aquaculture, 185: 235-243. https://doi.org/10.1016/ S0044-8486(99)00349-X

Rodrigues, F.C., Castro, A.S.B., Rodrigues, C.V., Fernandes, S.A., Fontes, E.A.F. and Oliveira, T.T., 2012. Yacon flour and Bifidobacterium longum modulate bone health in rats. J. Med. Fd., 15: 664670. https://doi.org/10.1089/jmf.2011.0296

Rowland, S.J. and Ingram, B.A., 1991. Diseases of Australian native fishes with particular emphasis on the ectoparasite and fungal diseases of Murray cod (Maccullochella peeli), golden perch (Macquaria ambigua) and silver perch (Bidyanus bidyanus). NSW Fisheries Bulletin Number 4, Sydney, Australia.

Sajjadi, M. and Carter, C.G., 2004. Effect of phytic acid and phytase on feed intake, growth, digestibility and trypsin activity in Atlantic salmon (Salmo salar L.) Aquacul. Nutr., 10: 135-142. https://doi. org $/ 10.1111 / \mathrm{j} .1365-2095.2003 .00290 . \mathrm{x}$

Salinas, I., Abelli, L., Bertoni, F., Picchietti, S. and Roque, A., 2008. Monospecies and multispecies probiotic formulations produce different systemic and local immuno stimulatory effects in the gilthead sea-bream (Sparus aurata L.). Fish Shellf. Immunol., 25: 114-123.

Shafaeipour, A., Yavari, V., Falahatkar, B., Maremmazi, J.G. and Gorjipour, E., 2008. Effects of canola meal on physiological and biochemical parameters in rainbow trout (Oncorhynchus mykiss). Aquacult. Nutr., 14: 110-119. https://doi.org/10.1111/j.13652095.2007.00509.x

Snedecor, G.W. and Cochran, W.G., 1991. Statistical methods, $8^{\text {th }}$ Ed. Iowa State University Press, Americans, USA, pp. 503.

Steel, R.G.D., Torrie, J.H. and Dickey, D.A., 1996. Principles and procedures of statistics, $3^{\text {rd }}$ Edn. McGraw Hill International Book Co. Inc., New York. USA, pp. 336-352.

Thiessen, D.L., Maenz, D.D., Newkirk, H.L., Classen, H.L. and Drew, M.D., 2004. Replacement of fishmeal by canola protein concentrate in diets fed to rainbow trout (Oncorhynchus mykiss). Aquacult. Nutr., 10: 379-388. https://doi.org/10.1111/j.13652095.2004.00313.x

Verschuere, L., Rombaut, G., Sorgeloos, P. and Verstraete, W., 2000. Probiotic bacteria as biological control agents in aquaculture. Microbiol. mol. Biol. Rev., 64: 655-671. https://doi.org/10.1128/ MMBR.64.4.655-671.2000

Wagner, A.D., Gabriel, J.D.E. and Verfaelie, M., 1997. Discussion between familiarity process in explicitrecognition and implicit-perceptual memory. J. exp. Psychol. Learn. Mem. Cogn., 23: 305-323. https:// doi.org/10.1037/0278-7393.23.2.305

Wang, K., Zhou, Y., Liu, H., Cheng. K., Mao, J., Wang, F., Liu, W., Ye, M., Zhao, Z.K. and Zou, H., 2015. Proteomic analysis of protein methylation in the yeast Saccharomyces cerevisiae. $J$. Proteom., 114: 226-233. https://doi.org/10.1016/j. jprot.2014.07.032

Watson, A.K., Kaspar, H., Lategan, M.J. and Gibson, L., 2008. Probiotics in aquaculture: The need, principles and mechanisms of action and screening processes. Aquaculture, 274: 1-14. https://doi. org/10.1016/j.aquaculture.2007.11.019

Watson, S., Chambers, D., Hobbs, C., Doherty, P. and Graham, A., 2008. The endocannabinoid receptor, $\mathrm{CB} 1$, is required for normal axonal growth and fasciculation. Mol. Cell Neurosci., 38: 89-97.

Wedemeyer, G.A. and Yastuke, W.T., 1977. Clinical methods for the assessment of the effects of environmental stress on fish health. U.S. Fish Wildl. Serv. Tech. Pap., 89.

Yue, Y.R. and Zhou, Q.C., 2008. Effect of replacing soybean meal with cottonseed meal on growth, feed utilization, and hematological indexes for juvenile hybrid tilapia, Oreochromis niloticus $\times$ O. aureus. Aquaculture, 284: 185-189. https://doi. org/10.1016/j.aquaculture.2008.07.030 